Cambronero-Solano, S., Tisseaux-Navarro, A., VargasHernández, J. M., Salazar-Ceciliano, J. P., BenavidesMorera, R., Quesada-Ávila, I., \& Brenes-Rodríguez, C. (2021). Hydrographic variability in the Gulf of Papagayo, Costa Rica during 2017-2019. Revista de Biología Tropical, 69(Suppl. 2), S74-S93. https://doi.org/10.15517/ rbt.v69iS2.48308

Biologín Tropical

https://doi.org/10.15517/rbt.v69iS2.48308

\title{
Hydrographic variability in the Gulf of Papagayo, Costa Rica during 2017-2019
}

Sergio Cambronero-Solano ${ }^{1,2}$; (iD https://orcid.org/0000-0002-3429-8672

Alexandre Tisseaux-Navarro'; (D) https://orcid.org/0000-0003-2634-2036

José Mauro Vargas-Hernández ${ }^{2}$; (D) https://orcid.org/0000-0002-7014-7054

Juan P. Salazar-Ceciliano ${ }^{1}$; (D) https://orcid.org/0000-0002-6951-5286

Rosario Benavides-Morera ${ }^{2}$; (D) https://orcid.org/0000-0002-8570-8280

Isabel Quesada-Ávila1; (D) https://orcid.org/0000-0002-3737-612X

Carlos Brenes-Rodríguez²; (D) https://orcid.org/0000-0002-7814-7673

1. Laboratorio de Oceanografía y Manejo Costero, Universidad Nacional, Costa Rica;

sergio.cambronero.solano@una.cr, alexandre.tisseaux.navarro@una.cr, juan.salazar.ceciliano@una.cr, isabel.quesada.avila@est.una.ac.cr

2. Servicio Regional de Información Oceanográfica, Universidad Nacional, Costa Rica; mauro@una.cr, rosario.benavides.morera@una.cr, cbrenes.una@gmail.com

Received 30-I-2021. Corrected 19-IV-2021. Accepted 28-VI-2021.

\begin{abstract}
Introduction: The Gulf of Papagayo (GP) is a site of socioeconomic importance located in the North Pacific of Costa Rica. The ecosystem services of this site represent a benefit in local communities, and its dynamics are influenced by a coastal upwelling system that affects fishing and commercial activity.

Objective: The objective of this study was to characterize the spatio-temporal variability of the main hydrographic parameters through measurements in situ during the period 2017-2019.

Methods: Eight measurement campaigns were carried out, where a CTD probe was deployed to perform vertical profiles in 23 stations distributed throughout the GP, to characterize the variations in temperature, salinity, dissolved oxygen and chlorophyll concentration.

Results: A minimum in surface and bottom temperature associated with upwelling caused by the wind was found in the first period of the year. The increase in salinity was associated with the decrease in temperature, being its highest value in the first period of the year, decreasing until reaching a minimum in November. The maximum chlorophyll concentration coincided with the lowest surface temperatures and the minimum oxygen values were associated with the minimum bottom temperatures, both occurring during the upwelling season. The parameter distribution was similar on dry and rainy seasons in stations located inside Bahía Culebra, likely attributed to the bathymetry effect.

Conclusions: Bathymetry determines a south-north asymmetry for salinity and temperature. Subsurface cooling events coincide with strong wind periods. Upwelling influences the surface and bottom hydrographic dynamic in GP and determines the seasonal variability. The negative ENSO phase of 2018 corresponded with the strongest upwelling period, possibly promoting the interaction of upwelled coastal waters and the Costa Rica Thermal Dome.
\end{abstract}

Key words: upwelling; Eastern Tropical Pacific; hydrography; ENSO; Gulf of Papagayo. 
The Gulf of Papagayo (GP) is in a region of high socioeconomic importance in the North Pacific of Costa Rica, where Bahía Culebra (BC) is the main center of tourism development in Costa Rica and Central America (Cajiao, 2012; Fig. 1). Located from Matapalo (Punta Gorda) up to the Santa Elena Peninsula, this gulf is influenced by one of three local upwelling ecosystems off the Pacific coast of Central America, which are generated by wind jets from high-pressure systems in the Gulf of Mexico and the Caribbean passing westward through mountain gaps in the isthmus (McCreary, Lee, \& Enfield, 1989). Wind gusts can reach up to $50 \mathrm{~ms}^{-1}$ at $10 \mathrm{~m}$ from the ground (Amador et al., 2006) and monthly average wind speed can reach 8 ms $^{-1}$ (Gómez, García, \& Álvarez, 2012). These wind jets spread offshore as far as $500 \mathrm{~km}$ off the Pacific coast, and have a time scale in the order of weeks (Fiedler \& Talley, 2006; Kessler, 2006).

It has been documented that funneling northeasterly winds through passages in the mountains produce upwelling in semi-enclosed bodies in the Pacific coast of Costa Rica (Brenes et al., 2003) and is the most important source of seasonal variability in GP (Fiedler \& Lavin, 2017). Strong-wind conditions are associated with vertical mixing and upwelling events because of Ekman pumping (Kessler, 2006). This influences the hydrography and composition of planktonic communities in GP, with the consequent transmission of energy at higher trophic levels (Ballestero, Márquez, Salazar, \& Murillo, 2012). Some of these events induce long-lived anticyclonic eddies with diameters between 100-450 km, which propagate westward and equatorward into the Eastern Tropical Pacific (ETP) (Ballestero \& Coen, 2004, Vargas 2002).

GP is in the ETP, a region off the coast of Central America and Mexico, delimited by Baja California to the North and Peru to the South (Fiedler \& Talley, 2006). This is one of the most complex oceanic regimes, where a wide variety of physical processes produce a coupled ocean-atmosphere system. According to McClain et al. (2012), surface meteorological processes such as wind stress patterns, heat fluxes and precipitation drive oceanic reactions such as vertical mixing, Ekman divergence, and a variety of wave modes such as Kelvin,

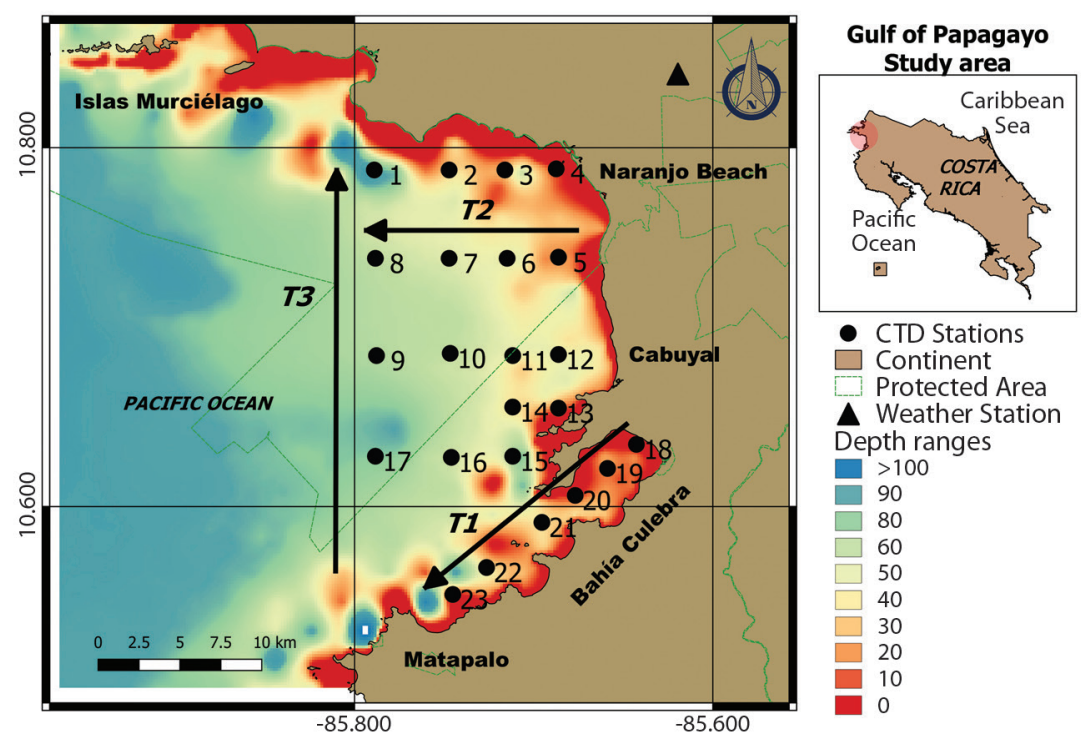

Fig. 1. Position of CTD casts done in the Gulf of Papagayo, Costa Rica. Arrows indicate the position of transects used to represent cross-sections. Bathymetric data were obtained from the General Bathymetric Chart of the Oceans (GEBCO Compilation Group, 2020). 
Rossby, Yanai and Kelvin-Helmholtz shear instabilities (Ménesguen et al., 2019)

Two major oceanographic conditions strongly influence the hydrographic variability in the ETP (Fiedler \& Lavin, 2017). Primarily, the Costa Rica Thermal Dome (CRTD), an upwelling region located off the coast of Nicaraguan and Costa Rican Pacific coast that affects the regional temperature distribution, as it represents the end of a thermocline ridge which shoals from west to east across the Pacific. CRTD is associated with local winds and the Equatorial Counter Current (Hofmann, Busalacchi, \& Q'Brien, 1981), this is of particular interest for GP as thermocline doming begins due to Ekman pumping near the coast in February-March (Fiedler, 2002). While CRTD is considered a mesoscale feature (McClain et al., 2002) with seasonal variability, lower frequency conditions such as El Niño-Southern Oscillation (ENSO) also influence the regional hydrography. During the positive phase of ENSO, sea surface temperature (SST) increase in the region, while on the negative phase ("La Niña"), SST drops significantly (Wolter \& Timlin, 2011). In this regard, it has been demonstrated that ENSO dominates the interannual variability in GP (Alfaro et al., 2012). In addition, the position of the intertropical convergence zone (ITCZ) also influences the hydrography of the region, particularly in coastal areas where river runoff can modify local conditions.

The physical complexity of GP makes it a unique ecological environment within the ETP, with a variety of understudied coastal environments (Álvarez, Benavides-Morera, BrenesRodríguez, \& Saxon, 2018) such as mangroves, sandy substrates, seagrass meadows, coastal islands, and rocky and coral reefs (May-Collado \& Morales, 2005). The ecosystem services provided by GP are important since some of the most developed coral reefs in Costa Rica can be found in GP at Islas Murciélago and BC (Jiménez \& Cortés, 2003). Additionally, the seasonality in GP is known to influence the presence of economically important species such as humpback whales, dolphins, sharks, squids, tuna and billfishes; this has made this place of particular interest for tourism and fisheries (Calambokidis, 2000; May-Collado, 2001; SINAC, 2008; Villalobos-Rojas, Herrera-Correal, Garita-Alvarado, Clarke, \& BeitaJiménez, 2014)

Tourism, conservation and restoration projects have increased over the last years in this area and have raised the need for proper management of marine resources. To achieve this, it is critical to understand the seasonal variability of the local and regional hydrography. Some of these relationships have been described in the past (Ballestero \& Coen, 2004; Brenes, Lavin, \& Mascarenhas, 2008; Vargas-Hernández, Salazar-Ceciliano, Benavides-Morera, Tisseaux-Navarro, \& Cambronero-Solano, 2019; Wyrtki, 1966), but there is a lack of comprehensive studies. Therefore, the objective of this work was to describe the hydrographic variations in the dry and rainy seasons in GP during the 2017-2019 period.

\section{MATERIALS AND METHODS}

Study area: The GP has an approximate area of $600 \mathrm{~km}^{2}$. Álvarez et al. (2018) indicated that the maximum depth in this area is $\sim 100$ m. According to IMN (2008) the climatology shows a clearly defined dry and rainy season, with a period of low precipitation between December and March, followed by two periods of high precipitation (Fig. 2): from May to June and then from August to October (Alfaro \& Cortés, 2012; Alfaro et al., 2012). These maximums are separated by a period of decreased precipitation, normally observed in July, called Mid-Summer Drought (also known as 'veranillo de San Juan' or 'canícula') (Alfaro, 2014; Magaña, Amador, \& Medina, 1999). April and November are transition periods between the dry and rainy seasons (Gotlieb, Pérez-Briceño, Hidalgo, \& Alfaro, 2019; Lizano \& Alfaro, 2014; Taylor \& Alfaro, 2005).

Data collection and analysis: We carried out eight measurement campaigns in the study area $(22 / 02 / 2017,07 / 09 / 2017,23 / 11 / 2017$, 


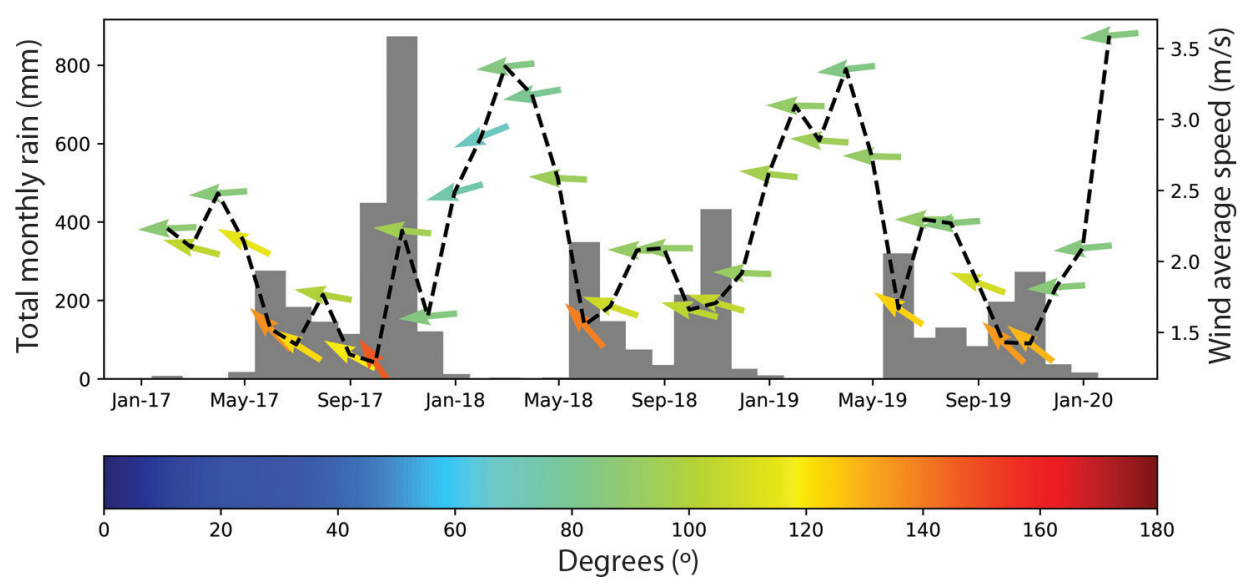

Fig. 2. Cumulative precipitation (bars), wind speed (line) and direction (arrows) monthly averages for the 2017-2019 research period, North Pacific of Costa Rica. The arrow color indicates the vector angle in reference to south.

28/02/2018, 12/09/2018, 27/11/2018, 20/03/2019 and 12/09/2019). The study area covered $350 \mathrm{~km}^{2}$, where vertical profiles of salinity, temperature, chlorophyll-a fluorescence, and dissolved oxygen concentration were recorded at 23 sampling stations. The 23 stations were sampled on all campaigns (Fig. 1) using two CTD sondes, an SBE19-Plus (sampling frequency: $4 \mathrm{~Hz}$, SeaBird Scientific) and EXO1 (sampling frequency: $1 \mathrm{~Hz}, Y S I$ ). The EXO1 was used instead of the SBE-19Plus in the first 3 three campaigns. Vertical profile data for the analyses were obtained only from the CTD sonde downcast. To further examine the spatial variability, stations were grouped in three transects, two longitudinal vertical sections across BC (T1) and off Naranjo Beach (T2), consisting of stations 18 to 23 for $\mathrm{T} 1$ and stations 5 to 8 for T2. The third transect comprised stations 23, 17, 9, 8 and 1 (T3), representing a latitudinal perspective in a streamwise direction.

CTD was towed manually at a constant speed between $0.2-0.4 \mathrm{~m} / \mathrm{s}$, filtering all data less than $0.15 \mathrm{~m} / \mathrm{s}$. The data for conservative temperature $\left({ }^{\circ} \mathrm{C}\right)$, absolute salinity $(\mathrm{g} / \mathrm{kg})$, chlorophyll-a concentration $\left(\mathrm{mg} / \mathrm{m}^{3}\right)$, and optical dissolved oxygen $(\mathrm{mg} / \mathrm{L})$ were averaged every $0.5 \mathrm{~m}$ and outliers were removed based on modified $z$-scores of the data set (Cho, Oh,
Kim, \& Shim, 2013; Virtanen, 2020). The horizontal distribution of properties at the surface and bottom were generated using the krigging method on standardized grids of 200 nodes in longitude and 250 in latitude. Oxygen data for February 2017 was excluded from the analyses due to technical problems with the CTD that produced invalid figures.

"To evaluate seasonality and possible interrelations of GP with the ENSO, we used 11 micron night-sea surface temperature (MODISA_L3m_NSST_Monthly_4km vR2019.0; GPS coordinates: 10.5791 \& -86.3503 ; $10.7769 \&-85.823)$ and chlorophyll-a concentration (MODISA_L3m_CHL v2018; GPS coordinates: $10.479 \overline{2}^{-} \&-86.8125 ; 10.8958$ \& -86.4792) from MODIS-Aqua radiometer to generate time series with a spatial resolution of $4 \mathrm{~km}$ on the GP region and monthlyaveraged from July 2002 to March 2021. We estimated the seasonality of the SST series with a periodic regression with cyclic descent as defined in Periods function by Gonzalez-Rodríguez, Villalobos, Gómez-Muñoz, \& Ramos Rodríguez (2015):

sst_2_harmonics

$=a_{0}+a_{1} \cos \left(\frac{2 \pi}{T_{1}} t+\varphi_{1}\right)+a_{2} \cos \left(\frac{2 \pi}{T_{2}} t+\varphi_{2}\right) \quad$ (Eq. 1$)$

where, $a_{0}, a_{1}, a_{2}$ and $a_{3}$ are amplitude harmonics adjustment in ${ }^{\circ} \mathrm{C} ; T_{1}$ and $T_{2}$ are the periods' 
harmonics adjustment in months, and $\varphi_{1}$ and $\varphi_{2}$ are phase in radians. Applying Eq. 1 to the time series, we obtained the period, amplitude and lag phase of the two main harmonic components of the SST time series (Table S1). To obtain the anomaly signal, we subtracted the harmonics from the original SST time series, this subtraction removes the influence of the annual cycle in SST series and allows the comparison with ENSO variability. From the resulting data, we calculated the association between SST in GP and ENSO by doing a cross-correlation of the filtered SST signal with the Oceanic Niño Index (ONI) (NOAA Climate Prediction Center).

We estimated the seasonality of the chlorophyll concentration series with Periods function and with three harmonic components:

$$
\begin{aligned}
& \text { chl_3_harmonics } \\
& =a_{0}+a_{1} \cos \left(\frac{2 \pi}{T_{1}} t+\varphi_{1}\right)+a_{2} \cos \left(\frac{2 \pi}{T_{2}} t+\varphi_{2}\right)+a_{3} \cos \left(\frac{2 \pi}{T_{3}} t+\varphi_{3}\right) \quad \text { (Eq. 2) }
\end{aligned}
$$

where, $a_{0}, a_{1}, a_{2}$ and $a_{3}$ are amplitude harmonics adjustment in chlorophyll concentration; $T_{1}, T_{2}$ and $T_{3}$ are the periods' harmonics adjustment in months, and $\varphi_{1}, \varphi_{2}$ and $\varphi_{3}$ are phase in radians. Applying Eq. 2 to the time series, we obtained the period, amplitude and lag phase of the three main harmonic components of the chlorophyll time series (Table S2). We calculated the association between chlorophyll and SST in GP by doing a cross-correlation of the raw monthly averaged data.

We visually evaluated the correspondence of in-situ measurements with remote sensing data from the MODIS-Aqua radiometer for chlorophyll and from the GHRSST Level 4 GISST products for sea surface temperature (Chao, Li, Farrara, \& Huang, 2009). Wind speed, wind direction and cumulative precipitation (Fig. 2) were obtained from meteorological station \#72163 of the IMN (Instituto Meteorológico Nacional: National Institute of Meteorology), located 315 meters above sea level in Santa Rosa, at the northwestern flank of GP.

\section{RESULTS}

We retrieved ENSO Sea Surface Temperature (SST) anomalies data for the research period, which corresponded to La Niña conditions in late 2017 and early 2018, and then transitioned to El Niño state in late 2018 and early 2019 (Table 1).

Vertical profile data of CTD had a depth range from 0 to $69 \mathrm{~m}$, the maximum depth point was registered in station 9, coinciding with the consulted bathymetry (Fig. 1). Parameters ranges were: temperature 12-31 ${ }^{\circ} \mathrm{C}$, salinity $30-36 \mathrm{~g} / \mathrm{kg}$, chlorophyll 0-7.5 mg/ $\mathrm{m}^{3}$, oxygen $0-8.5 \mathrm{mg} / \mathrm{L}$. Results are presented to evaluate horizontal and vertical distribution, first the surface and bottom interpolations in all the research area, then the vertical distribution variation of the farthest and closest station to the coast during the research period. In addition to this, cross-sections of GP based on transects T1, T2 and T3 are shown for the four

TABLE 1

Warm (red) and cold (blue) periods based on a threshold of $+/-0.5^{\circ} \mathrm{C}$ for the Oceanic Niño Index (ONI), based on centered 30 -year base periods updated every 5 years. Yellow boxes represent the temporal extent of this research. Adapted from NOAA website (Climate Prediction Center Internet Team)

\begin{tabular}{ccccccccccccc}
\hline Year & DJF & JFM & FMA & MAM & AMJ & MJJ & JJA & JAS & ASO & SON & OND & NDJ \\
\hline 2015 & 0.6 & 0.6 & 0.6 & 0.8 & $\mathbf{1 . 0}$ & $\mathbf{1 . 2}$ & $\mathbf{1 . 5}$ & $\mathbf{1 . 8}$ & $\mathbf{2 . 1}$ & $\mathbf{2 . 4}$ & $\mathbf{2 . 5}$ & $\mathbf{2 . 6}$ \\
2016 & $\mathbf{2 . 5}$ & $\mathbf{2 . 2}$ & $\mathbf{1 . 7}$ & $\mathbf{1 . 0}$ & $\mathbf{0 . 5}$ & 0.0 & -0.3 & $\mathbf{- 0 . 6}$ & $\mathbf{- 0 . 7}$ & $\mathbf{- 0 . 7}$ & $\mathbf{- 0 . 7}$ & $\mathbf{- 0 . 6}$ \\
2017 & -0.3 & -0.1 & 0.1 & 0.3 & 0.4 & 0.4 & 0.2 & -0.1 & -0.4 & $\mathbf{- 0 . 7}$ & $\mathbf{- 0 . 9}$ & $\mathbf{- 1 . 0}$ \\
2018 & $\mathbf{- 0 . 9}$ & $\mathbf{- 0 . 8}$ & $\mathbf{- 0 . 6}$ & -0.4 & -0.1 & 0.1 & 0.1 & 0.2 & 0.4 & $\mathbf{0 . 7}$ & $\mathbf{0 . 9}$ & $\mathbf{0 . 8}$ \\
2019 & $\mathbf{0 . 8}$ & $\mathbf{0 . 8}$ & $\mathbf{0 . 8}$ & $\mathbf{0 . 7}$ & $\mathbf{0 . 6}$ & $\mathbf{0 . 5}$ & 0.3 & 0.1 & 0.1 & 0.3 & 0.5 & 0.5 \\
\hline
\end{tabular}


parameters. Results for the surface level are shown in Fig. 3.

Surface observations: In all campaigns, the horizontal distribution of temperature at the surface showed a marked seasonal pattern (Fig. 3A). For the three years, the temperature was lower in the first trimester of the year and higher during the last trimester. The coldest temperature was recorded in February 2018, and the warmest in September 2017; lower values were generally associated with the northern part of GP. As for salinity, the highest values coincide with the coldest campaign in February 2018 (Fig. 3B). Minimum values of salinity (30-32 $\mathrm{g} / \mathrm{kg}$ ) were recorded in November 2018 in the whole study area, and in the south of GP in February 2017 and September 2019.

Oxygen distribution was homogeneous across GP in September 2017, while heterogeneity was seen on other campaigns (Fig. 3C). In February 2017, the southern flank of GP showed values of $7 \mathrm{mg} / \mathrm{L}$, higher than the rest of the gulf. In November 2017 and November 2018, high concentration values were associated with the inner part of BC. A local surface oxygen minimum was detected in February 2018 between Cabuyal and Naranjo Beach, with a concentration less than $6.5 \mathrm{mg} / \mathrm{L}$, while in September 2018 the minimum oxygen values were inside BC. Chlorophyll-a concentration shows a similar pattern to oxygen and salinity, higher in the first trimester and generally decreasing over the year (Fig. 3D). Chlorophyll distribution was homogenous across GP in September 2018 and November 2018. In February 2017, the minimum concentration was inside $\mathrm{BC}$, while the maximum was associated to the north flank, off Naranjo Beach.

In September 2017 a chlorophyll maximum was recorded in the outer part of GP close to station 8, while in November 2017 a maximum of $2 \mathrm{mg} / \mathrm{m}^{3}$ was present in the inner part of BC. We recorded a particularly high concentration of chlorophyll in February 2018, which coincided with the highest values of salinity, in the coldest campaign and the aforementioned site of local oxygen minimum between Cabuyal and Naranjo Beach.

Bottom observations: We generated bottom level interpolations to visualize the relationships with the surface (Fig. 4). In comparison to the surface; we found colder waters throughout the whole area, as expected for tropical latitudes where temperature decreases over depth. The temperature at the bottom showed a similar seasonal variability to the surface (Fig. 4A), with the lower values during February and warmer water in September and November. September campaigns showed the $20^{\circ} \mathrm{C}$ isotherm around the $50 \mathrm{~m}$ and $60 \mathrm{~m}$ isobaths, with colder waters $\left(17^{\circ} \mathrm{C}\right)$ than the data from November, which minimum value recorded was $19^{\circ} \mathrm{C}$ at station 17 .

There was a horizontal gradient found in all campaigns, the bottom temperature in the inner part of $\mathrm{BC}$ remained always warmer than the rest of the area, we also noted this behavior in the northeast region of GP, in Naranjo Beach for September, November and March. In this regard, salinity values also coincided with the temperature values, being lower in $\mathrm{BC}$ and Naranjo Beach, associated with the stations closer to the coast and around estuaries due to the inputs of freshwater (Fig. 4B).

The coastal stations were generally welloxygenated at the bottom, with values ranging between 4-6 mg/L (Fig. 4C). Low oxygen values (less than $2 \mathrm{mg} / \mathrm{L}$ ) were always present in the outer part of GP, deeper than $50 \mathrm{~m}$. On the other hand, anoxic conditions $(<0.5 \mathrm{mg} / \mathrm{L})$ were recorded in February 2018 and September 2018-2019, farthest from the coast in February and closest to Peninsula Papagayo and $\mathrm{BC}$ in September.

The highest chlorophyll concentrations were found in September and November, which contrasted with low concentration values found at the surface in these same months. Normal to high concentrations from 0.5 to $3 \mathrm{mg} / \mathrm{m}^{3}$ were present in all campaigns on $\mathrm{BC}$, with a particular maximum in November 2017 (Fig. 4D). 

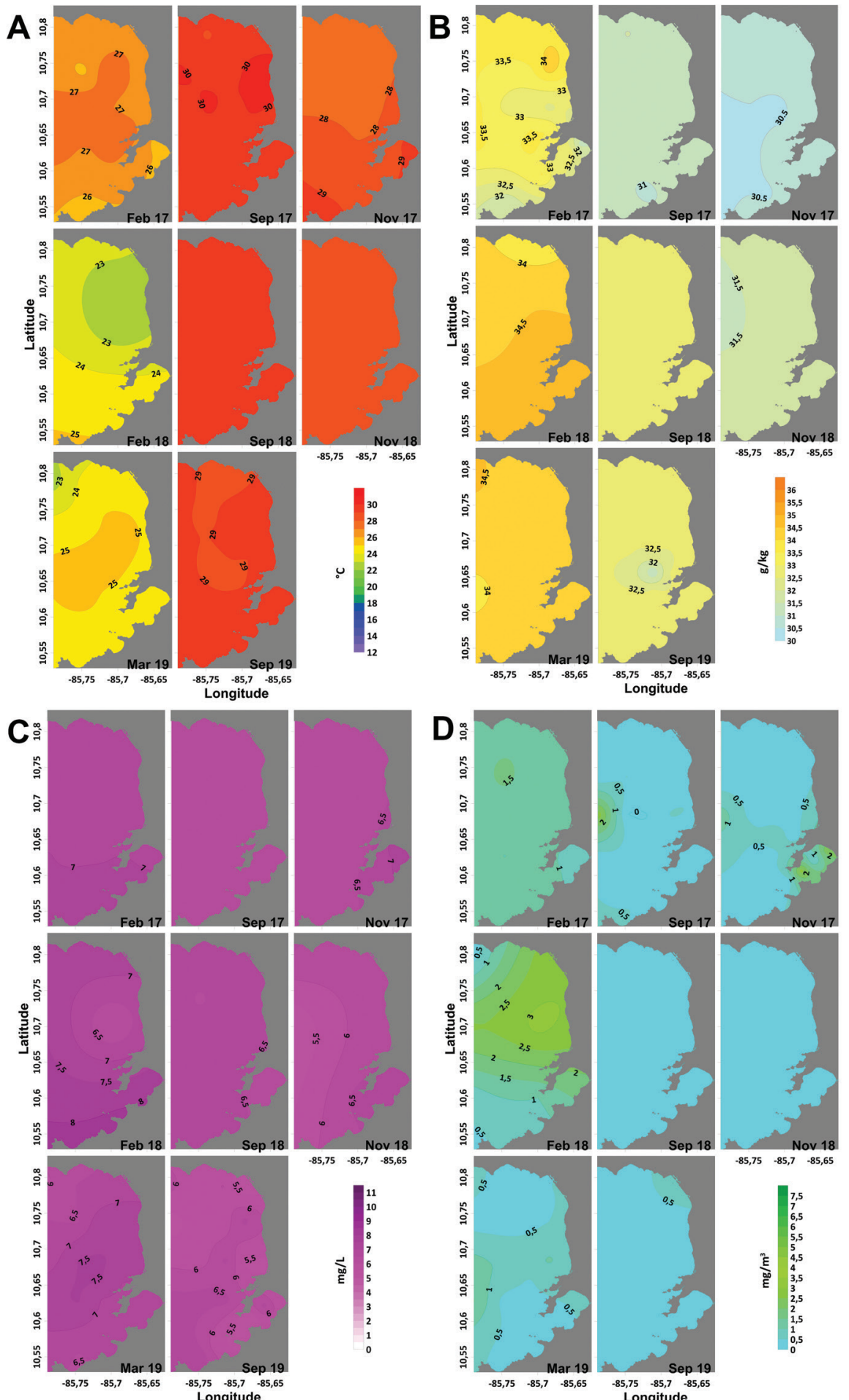

Fig. 3. Surface distributions of Conservative Temperature (A), Absolute Salinity (B), Oxygen (C), and Chlorophyll (D) of eight sampling in the Gulf of Papagayo, Costa Rica. 
A :
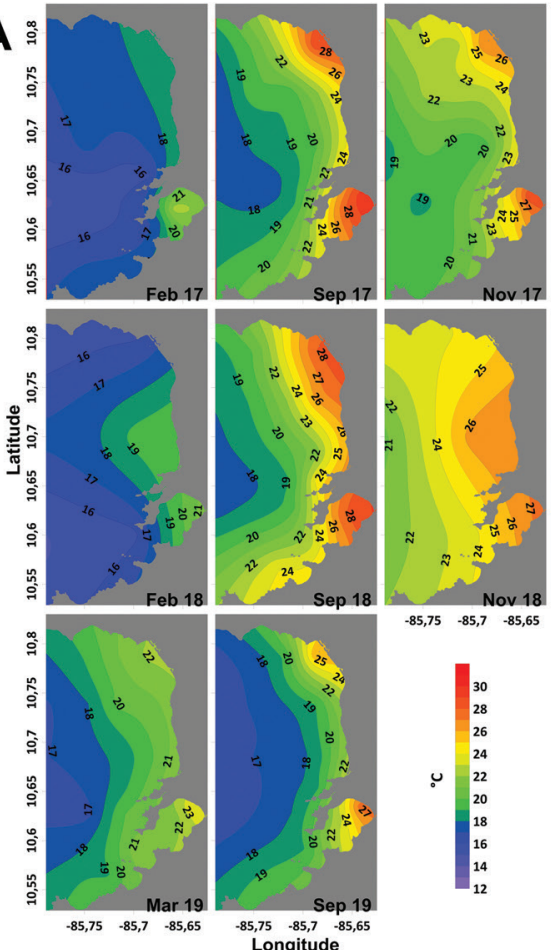

\section{C}
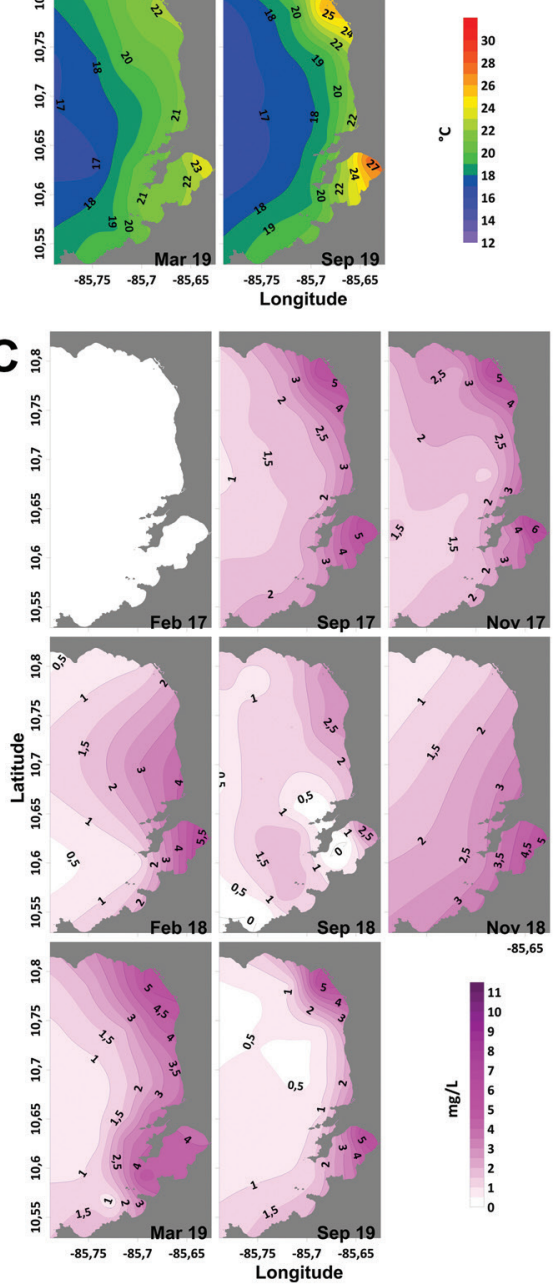
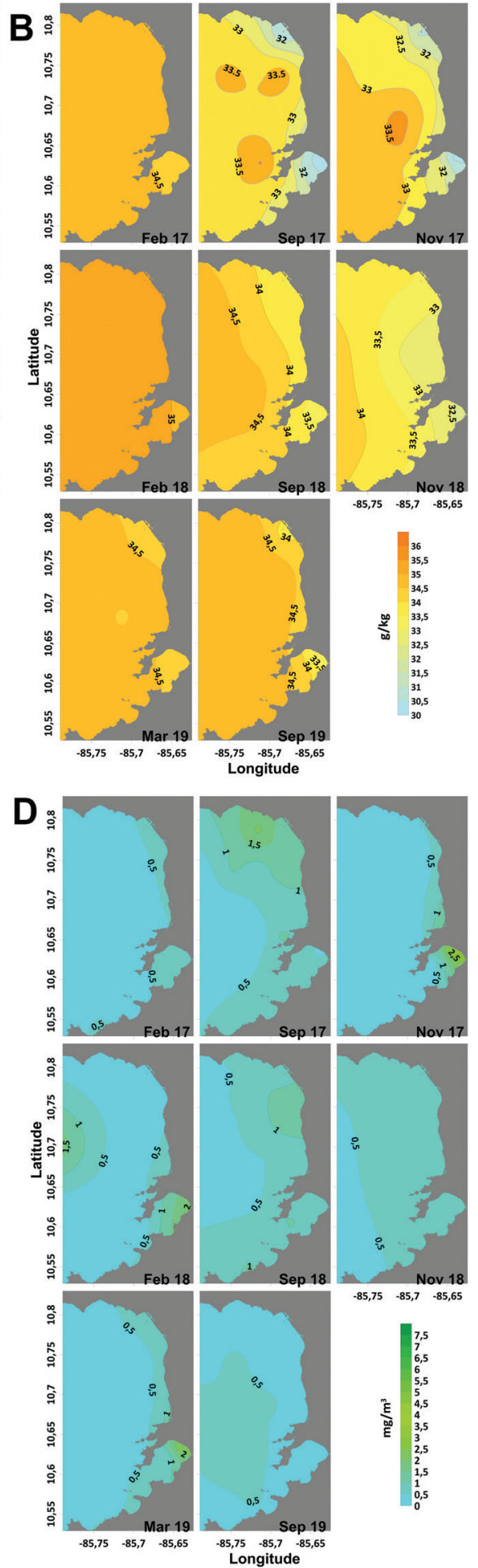

$-85,75 \quad-85,7 \quad-85,6$

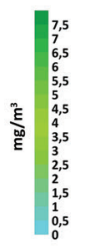

Fig. 4. Bottom distributions of Conservative Temperature (A), Absolute Salinity (B), Oxygen (C) and Chlorophyll (D) of eight sampling campaigns in the Gulf of Papagayo. Data for Feb-17 oxygen was invalid and not included. 
Vertical structure: We evaluated the vertical structure temporal variability by comparing the farthest and nearest to coast stations (Fig. 5). These graphs (Fig. 5) show the difference in vertical structure among all the parameters and give insight into the three-dimensional variability across depths. We found differences in the vertical distribution of parameters between stations 17 and 18. In station 18, inside BC, the vertical structure shows a homogenous column for temperature and salinity. On the other hand, station 17 shows a well-defined thermocline that shoals around $30 \mathrm{~m}$ in the upwelling months.

The thermocline had the shallowest portion (10-15 meters) in February 2018 (Fig. 5 ), associated with the maximum wind speed recorded in the 2017-2018 period (Fig. 2). This shows that upwelling or vertical mixing events influence the whole area of GP while causing the highest variation and coldest waters in the outer parts of GP (Fig. 5A). In contrast, Fig. 5B shows a weaker stratification in coastal stations, where values of temperature, oxygen and chlorophyll denoted two layers over the vertical profile, while the salinity was generally homogeneous. Temperature distribution suggests that shallow areas inside BC could be affected by the advection from colder waters in the surroundings of the bay and by the vertical mixing induced by wind stress. Tidal forcing could influence vertical mixing, although it was not within the scope of this study.

We recorded minimum salinity values (30$31 \mathrm{~g} / \mathrm{kg}$ ) in November 2017, when the entire water column in station 18 decreased its salinity below $33 \mathrm{~g} / \mathrm{kg}$, and in contrast with values on station 17 , where low salinity was evident only in the surface level $(0-5 \mathrm{~m})$. The salinity distribution, in conjunction with meteorological data (Fig. 2), suggests that salinity descends in GP because of runoff and river discharge, and this could have a higher effect on the vertical structure of coastal areas rather than outer GP. Other factors such as advection, solar radiation incidence and tidal forcing may also play a role in the dynamics but were not within the scope of this study.
The $25{ }^{\circ} \mathrm{C}$ isotherm fluctuates from $10 \mathrm{~m}$ during high wind intensity to approximately 40 $\mathrm{m}$ in November (Fig. 5A), shoaling in BC only during the first trimester. This isotherm coincides with the chlorophyll concentration peaks. The subsurface chlorophyll maximum shifted between $10-15 \mathrm{~m}$ on station 17 , and remained at a range of four meters from the bottom inside $\mathrm{BC}$, on station 18. A maximum chlorophyll concentration of $7.5 \mathrm{mg} / \mathrm{m}^{3}$ was registered in February 2018, evidencing a correspondence between high-intensity wind periods and primary productivity peaks.

Low-oxygenated waters were associated with high magnitude winds and predominant $80^{\circ}$ from the north direction during the first trimester, values less than $1 \mathrm{mg} / \mathrm{L}$ were found at the bottom level, in outer GP below $40 \mathrm{~m}$, and inside $\mathrm{BC}$ below $10 \mathrm{~m}$. Our results show that the first $20 \mathrm{~m}$ in GP remain always well oxygenated. Anoxic conditions were recorded in February 2018 and September 2018 for station 17 , while inside $B C$ values less than $0.5 \mathrm{mg} / \mathrm{L}$ were present in September 2018 and March 2019. In general, horizontal gradients showed similar values inside BC (stations 18-23).

To further inspect the dynamics on the vertical dimension in GP, we visualized the three-dimensional variability of the gulf during September campaigns (Fig. 6): two longitudinal-vertical sections that extend across $\mathrm{BC}$ (T1) and off Naranjo Beach (T2), as well as a latitudinal perspective in streamwise direction (T3). Cross-sections are shown for the September campaigns.

The thermal and salinity structure indicated that in September, depth gradient limits the intrusion of colder water into the inner parts of BC, where water in stations 20, 19 and 18 was usually warmer. North-South temperature asymmetry was identified, as the $20{ }^{\circ} \mathrm{C}$ isotherm was shallower in the north flank of GP, on stations that are 10-20 m deeper than the south flank. Strong stratification happens during September (Fig. 6A; Fig. 6B), coinciding with low to moderate average wind speeds of $1-2 \mathrm{~m} / \mathrm{s}$ and low precipitation, below 200 $\mathrm{mm}$ of total monthly rain (Fig. 2). Based on 
A Conservative Temperature, Station 17
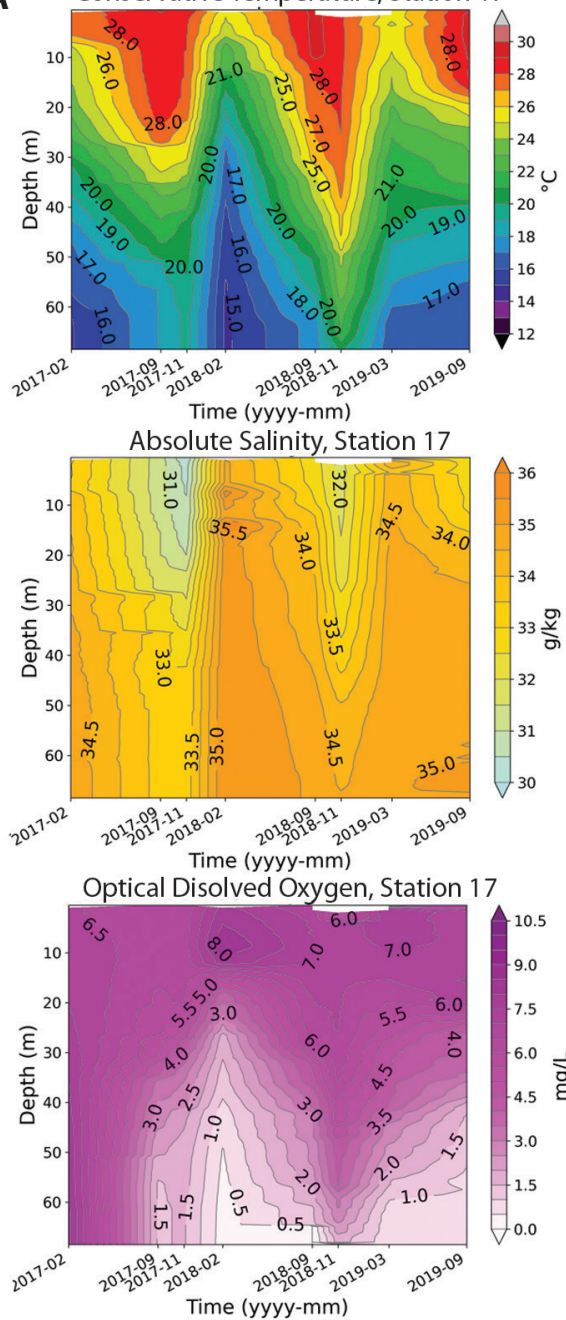

\section{7}

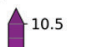

B Conservative Temperature, Station 18
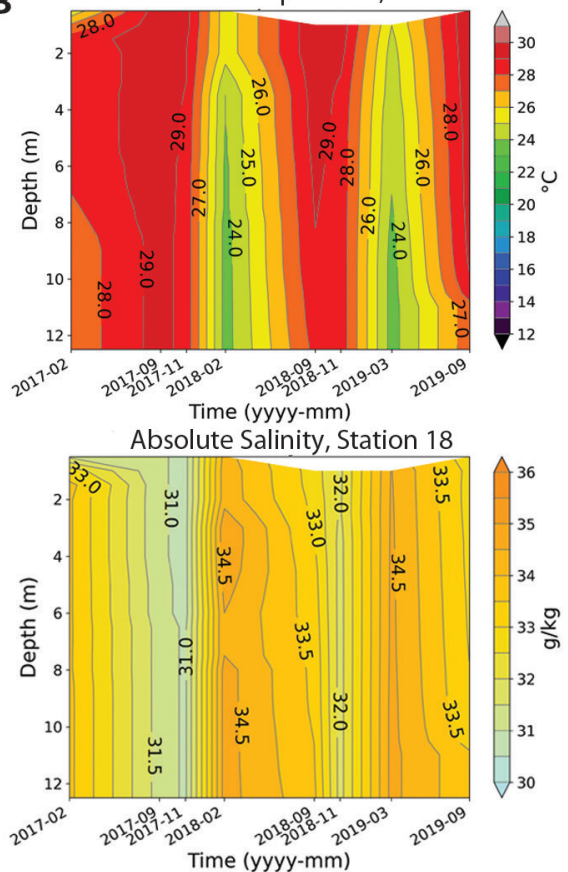

Optical Disolved Oxygen, Station 18
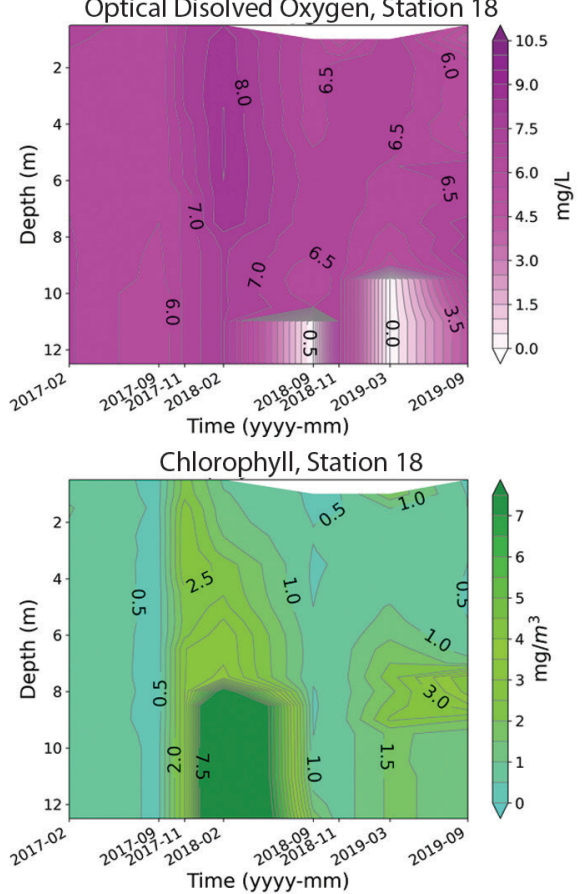

Fig. 5. Time series distribution of conservative temperature, absolute salinity, dissolved oxygen and chlorophyll across depth in the farthest and closest to coast stations (17 and 18, respectively). 

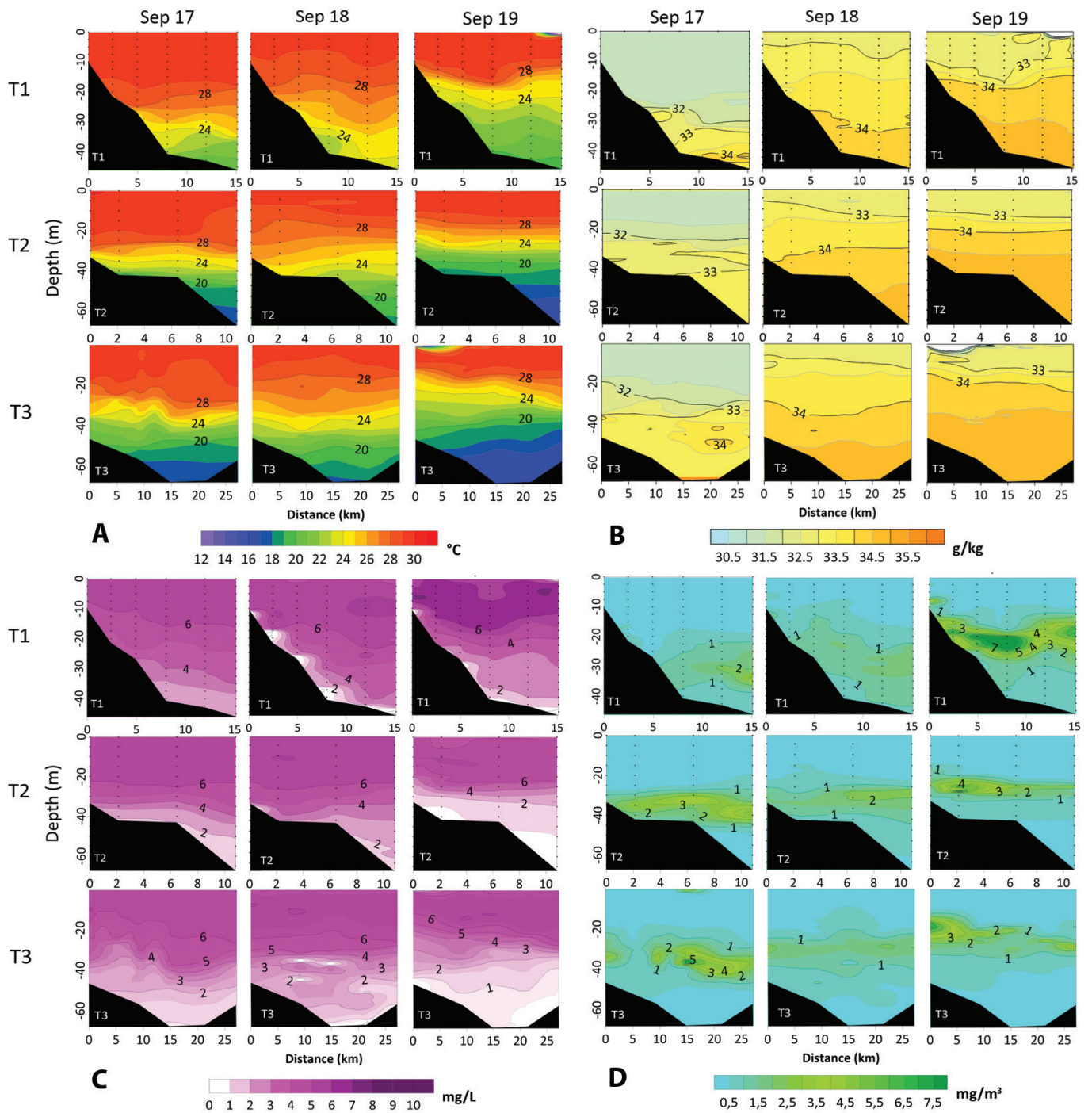

Fig. 6. Longitudinal (T1, T2) and latitudinal (T3) cross-sections showing the vertical profile interpolations of conservative temperature (A), absolute salinity (B), dissolved oxygen (C) and chlorophyll-a concentration (D) in September 2017, 2018 and 2019. Distance 0 is located on the coast.

temperature, the mixed layer was wider during September 2017 (30 m), and narrower in September 2019 (15 m).

The salinity vertical structure during the rainy season showed low salinity values $(<32$ $\mathrm{g} / \mathrm{kg}$ ) on the first $10 \mathrm{~m}$ of the water column (Fig. 6B), with September 2017 showing the lowest values. High salinity nucleus ( $>34 \mathrm{~g} /$ $\mathrm{kg}$ ) was found to be associated with deeper areas, in the north flank and outer stations of GP, with the maximum salinity recorded between 40-50 m in September 2018 and 2019.

Oxygen distribution in September showed low oxygenated waters (Fig. 6C) associated with bottom level, for the three years, although in September 2017 minimum oxygen concentration was $1 \mathrm{mg} / \mathrm{L}$, while in September 2018 anoxic values were recorded on $\mathrm{BC}$ and off 
Cabuyal, at midwater level $(40-50 \mathrm{~m})$. The anoxic layer was wider in September 2019, when oxygen distributed asymmetrically on GP, with higher values on the south flank and anoxic values in the deeper areas. The subsurface chlorophyll maximum was located between 20-40 $\mathrm{m}$ in September (Fig. 6D), with chlorophyll concentration maximum on September 2019, inside BC near station 21. In September 2017 the chlorophyll concentration

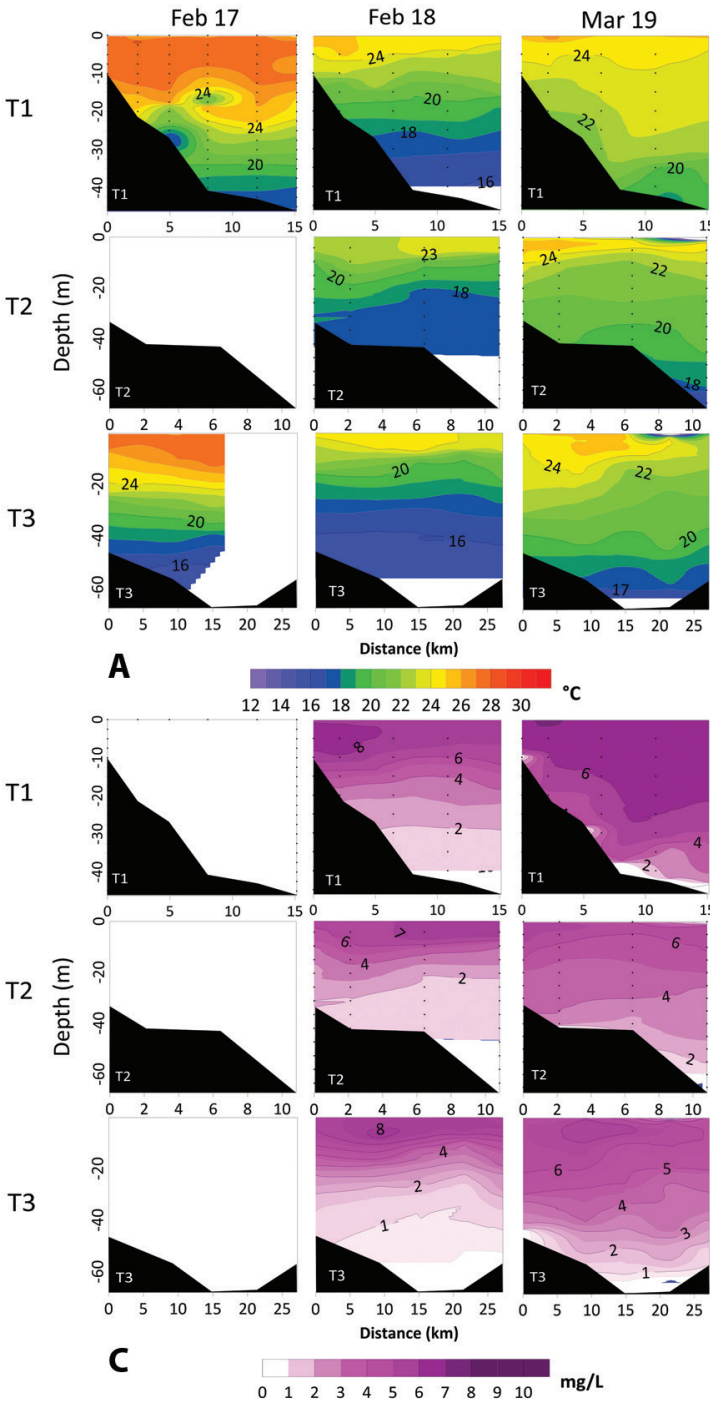

peak was located off Cabuyal, around $40 \mathrm{~m}$ deep on the deep channel, and September 2019 showed a clear chlorophyll distribution asymmetry with high values on the southern flank of GP and lower values at the north flank.

SST time series retrieved from satellites confirmed our minimum SST record in February 2018 and evidenced a well defined seasonal variability in the GP region. Fig. 7 shows that monthly averaged SST decreases in the first
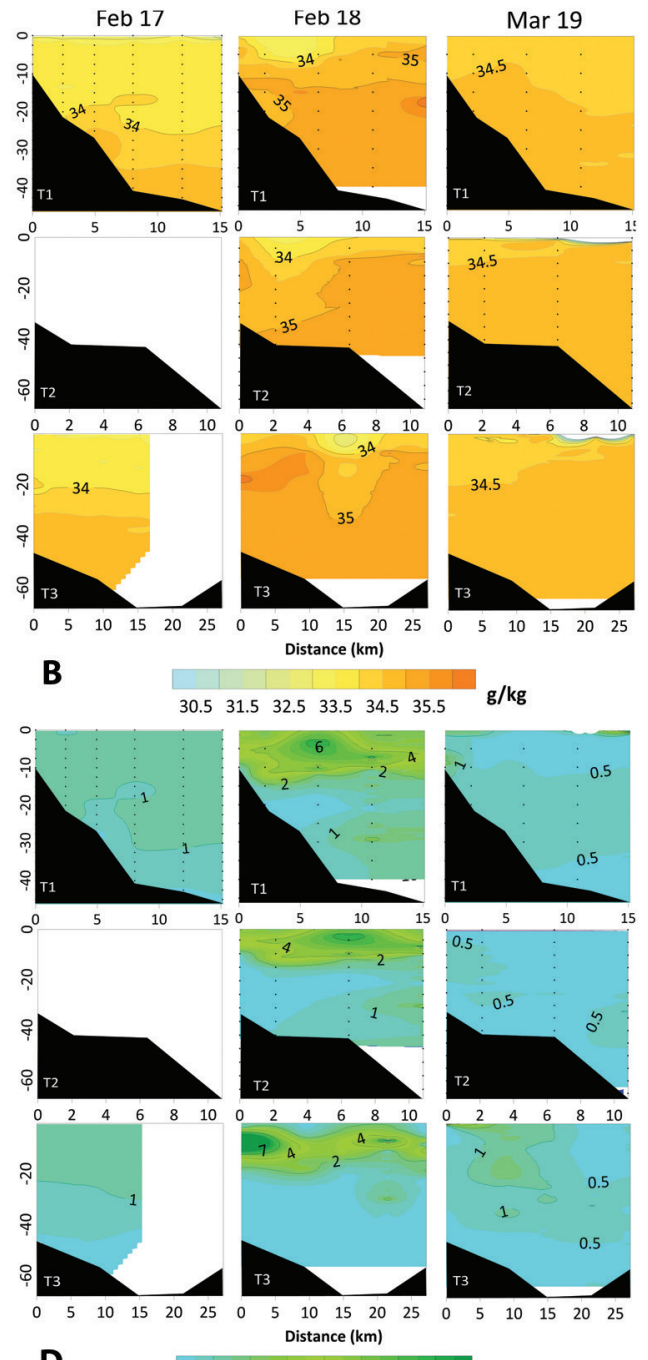

D

Fig. 7. Longitudinal (T1, T2) and latitudinal (T3) cross-sections showing the vertical profile interpolations of conservative temperature (A), absolute salinity (B), dissolved oxygen (C) and chlorophyll-a concentration (D) in February 2017,2018 and March 2019. Distance 0 is located on the coast. T2 data was not available for Feb 17 and oxygen data on Feb 17 was categorized as invalid. 

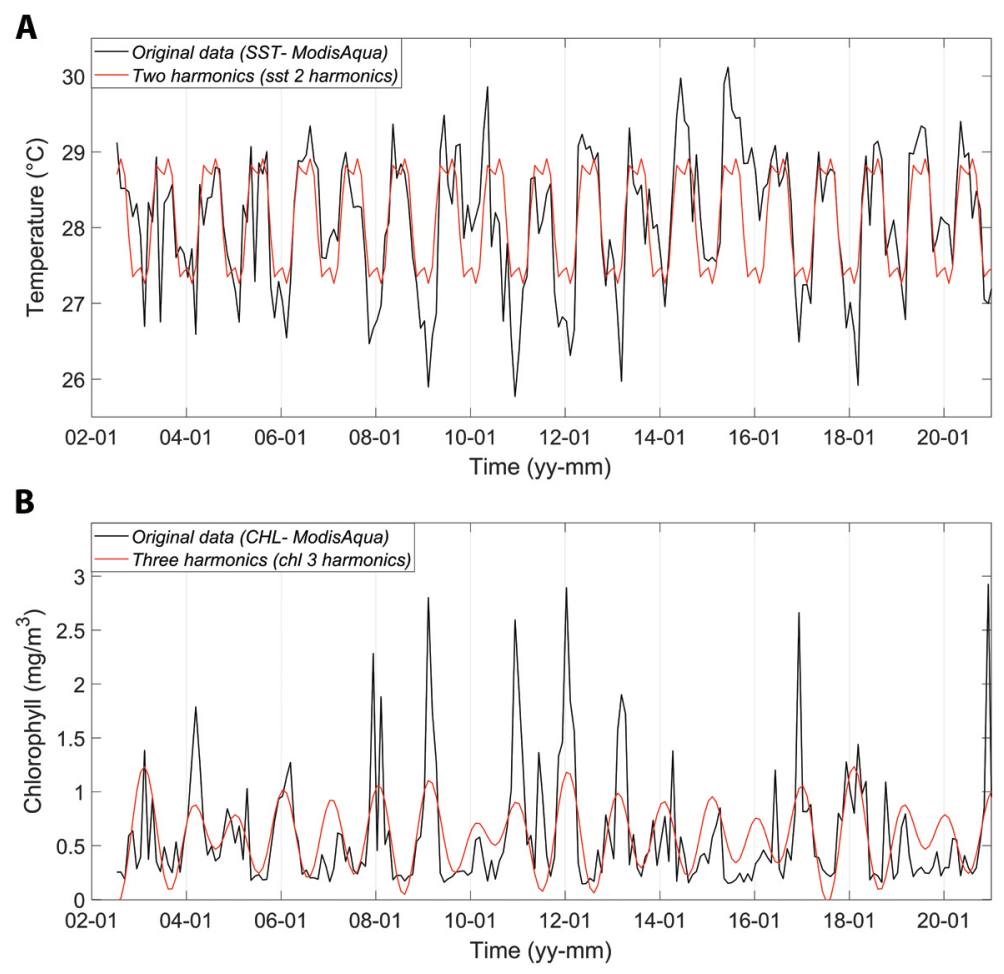

Fig. 8. Time series (2002-2021) of: (A) monthly averaged SST with two harmonic components used to obtain the anomaly signal (periods $=12$ and 4 months; $\mathrm{R}^{2}=0.513 ; \mathrm{P}$-value $=1.901 \mathrm{e}^{-34}$ ); and $(\mathrm{B})$ monthly averaged chlorophyll with three harmonic components (periods $=12,18$ and 15 months; $\mathrm{R}^{2}=0.316$; $\mathrm{P}$-value $=1.376 \mathrm{e}^{-16}$ ).

trimester and then increases in the subsequent months (Fig. 8A), the temperature variability range was approximate $\pm 2{ }^{\circ} \mathrm{C}$. SST averages showed that lower values coincide with strong wind periods reported for the area during December to March period.

The 2-harmonic analyses (Fig. 8A) of the SST time series showed that the first harmonic period for the region is of 12 months and $\sim 0.8$ ${ }^{\circ} \mathrm{C}$ of amplitude, while the second harmonic period was 4 months with an amplitude of $0.4{ }^{\circ} \mathrm{C}$ (Table S1). Cross-correlation between the calculated SST anomaly and ONI showed a maximum positive correlation at 0 -months time lag. This means that the ENSO effect on SST in GP happens immediately with no lag $(\mathrm{P}<0.05)$, confirming our results concerning the ONI phase and in-situ surface temperature. The harmonic analyses of chlorophyll showed the first harmonic of 12 months, second of 18 months and third of 15 months (Table S2). Cross-correlation between chlorophyll and SST showed a negative correlation at 0 -months time lag.

\section{DISCUSSION}

The hydrographic variability of GP during the research period confirms that seasonal upwelling events influenced the horizontal and vertical gradients during the first trimester. Our results show the correspondence of subsurface cooling events to high wind speed as described by Alfaro and Cortés (2012). During the research period, wind magnitudes higher than $2.0 \mathrm{~m} / \mathrm{s}$ coincided with the colder surface and bottom temperature values in the entire gulf. According to Barua (2005), wind forcing drives coastal upwelling, which could be 
associated with three different processes that apply to GP context, in relation to the geomorphology of the coast and its interaction with wind fields: alongshore wind, offshore/onshore wind and open ocean divergence/convergence.

Results showed a predominant northeasterly wind direction $\left(60-90^{\circ}\right)$, which partially satisfies the alongshore wind condition in the northern and southern flank of GP. At the north, the Peninsula de Papagayo coastline extends in a SE-NW direction, with small bays, river mouths and cliffs that could experiment downwelling as they are upward from the wind direction. On the other hand, the southern flank extends on a NE-SW, parallel to the wind direction and thus fulfilling the condition for alongshore upwelling. In this regard, upwelling in GP could be further influenced by the offshore wind that blows perpendicular to the coast, as the section from Cabuyal to Naranjo Beach fulfills this condition; this was proved by our results based on temperature and chlorophyll concentration distribution. The third underlying mechanism of the observed upwelling could be the open ocean divergence represented by the CRTD. Although some of these aspects can be inferred from the data collected in this study, the validation of these hypotheses must be inspected further through ADCP mooring data and wind field cross-correlation products.

Although the three upwelling periods in our records have shown a reduction in temperature, February 2017 showed warmer values at the surface level which could be attributed to weaker winds than in February of 2018 and 2019. In contrast, March's bottom temperature in 2019 was warmer than in the other years, during the positive ENSO phase. During the research period, the temperature inside $\mathrm{BC}$ was warmer than the rest of the gulf.

The three ENSO phases were present during the research period. First, a strong "La Niña" event from October 2017 to March 2018 cooled down the waters to $12{ }^{\circ} \mathrm{C}$ at the bottom of GP, probably because of stronger winds (Wang \& McPhaden, 2001). In contrast, the "El Niño" event that took place from October 2018 until June 2019 was associated with the warmest waters of all the September campaigns. When we compare the first trimester of the three years, for 2017 it was in the neutral phase of ENSO while 2018 was negative and 2019 was a positive phase. The latter being the warmest upwelling period at the bottom level. Although bottom water was below $15^{\circ} \mathrm{C}$ in GP in February 2017, inside BC the temperature remained warmer than the rest of the gulf. We suggest this could be caused by low magnitude winds in the first months of 2017, with an average speed not surpassing $2.5 \mathrm{~m} / \mathrm{s}$, while 2018 and 2019 showed values higher than $3.0 \mathrm{~m} / \mathrm{s}$, this could have lead to reduced vertical mixing inside BC. Based on these facts, we suggest that a wind magnitude threshold of $3 \mathrm{~m} / \mathrm{s}$ could lead to the shoaling of the thermocline in the inner part of BC. These results confirm the important effects of ENSO on the interannual variability (Marrari, Piola, \& Valla, 2017)

Observations of seawater temperature confirm that the Gulf of Papagayo experiences significant seasonal differences, based on contrasting values associated with strong winds during the first trimester (Jiménez, 2001) and the rainy season in the third and fourth trimester. The heterogeneity in the horizontal distribution of properties shows that these upwelling events may have different extents and effects inside $\mathrm{BC}$, where bathymetry seems to play an important role in local circulation, as well as the solar radiation incidence on shallower areas, horizontal advection with surrounding waters of GP and vertical mixing by wind and/ or tidal forcing. The evidence found suggests that the hydrography and circulation in shallower areas like in $\mathrm{BC}$ could be dominated by vertical mixing and tides, while deeper areas in outer GP could be more influenced by upwelling processes.

Time-series analyses showed that seasonality is well defined for the GP area, meaning that winds have a strong influence on the evolution of SST along the year (Alfaro et al., 2012). Cross-correlation results confirmed the direct association between SST and ENSO phase (lag $0, \mathrm{P}<0.05$ ) and SST with chlorophyll (lag 0 , $\mathrm{P}<0.05$ ), coinciding with annual variability of 
in-situ observations and with previous studies done by Alfaro and Lizano (2001), who calculated a significant lag of $\sim 2$ months through the decomposition of a 50-year SST time series. This means that ENSO is the main influence over the Northeastern Tropical Pacific, with positive correlations with no delay. Although the ENSO effect was confirmed, the twoharmonic model only explains $\sim 60 \%$ of the time series, on this regard, it has been indicated that this area is subject to another synopticscale variability such as Kelvin waves, the Pacific Decadal Oscillations, ATN and ATS oscillations (Alfaro \& Lizano, 2001; Jia, Chen, \& Zuo, 2017; Trasviña, Lluch, Filonov, \& Gallegos, 1999). Chlorophyll showed a significant inverse correlation with SST, confirming in-situ results.

A visual evaluation of the spatial patterns of chlorophyll-a concentration and its relationship with CRTD was done through a visual comparison of the collected data, and satellite data for the specific dates when sampling was done. February 2017 range of values coincided with the satellite measurements for GP (Fig. $\mathrm{S} 1$ ), specifically with values greater than 3 $\mathrm{mg} / \mathrm{m}^{3}$ at the north flank of GP. Satellite data for September 2017 were not available for the extension of GP, probably due to weather conditions. November 2017 satellite-derived chlorophyll concentration range and distribution also coincided with in-situ measurements. In February 2018, during the upwelling period, we recorded anomalous concentration values that corresponded to a negative anomaly value of the ENSO index. The subsequent months of 2018 match the in-situ concentrations, both showing a low concentration all over GP and throughout $87^{\circ} \mathrm{W}$. In March 2019, satellitederived values indicated low chlorophyll concentration, opposite to in-situ data that showed surface concentrations up to $2 \mathrm{mg} / \mathrm{m}^{3}$.

The difference in values of chlorophyll-a concentration may be attributed to the temporal resolution of the visually compared data, as CTD data were only measured once while satellite data shows weekly averaged values. Based on this, we suggest that for March 2019, in-situ data could have recorded a short-lived event caused by the off-shore wind blowing and thus, it was not reflected on the satellite weekly average. Another explanation could be attributed merely to the optics nature of the sensors compared, as the CTD fluorescence sensor captures different signals than the MODIS-Aqua radiometer. In this regard, Salyuk et al. (2010) indicate that fluorometers could have large errors in coastal waters where rivers and anthropogenic activity impact the concentration of Dissolved Organic Matter (DOM), affecting the optical accuracy of measurements as chlorophyll-a fluorescence signal mixes with the DOM signal.

SST data from GP surrounding waters was retrieved through a longitudinal section of approximately $130 \mathrm{~km}$ offshore GP (Fig. S2). This data shows a pattern of low temperature during the first trimester and higher temperatures over the rest of the year, matching in-situ results obtained in GP. The interannual variability detected from satellite sensors showed warmer SST for the first trimester of 2017, in comparison to 2018 and 2019. Although this is supported by our data, it is important to note that satellite data indicated lower SST values in January and March 2017, which could be influenced by low wind stress in that month (monthly average less than $2.0 \mathrm{~m} / \mathrm{s}$ ). In Fig. S2, lines 1, 4 and 7 represent upwelling period sampling, which can be appreciated by cold water extending from $87^{\circ} \mathrm{W}$ all over to GP. For the first trimester of 2018, a large spatiotemporal extension of cold waters below $23{ }^{\circ} \mathrm{C}$ was detected during ENSO negative anomaly (-0.8) from -87.0 to -86.30 , extending further eastward in comparison to 2017 and 2019. The minimum temperature values in February 2018 coincided with in-situ data of GP. We suggest that ENSO negative phase increased the extension of low SST values. The low SST can also be associated with the CRTD and its interaction with the continental shelve and coastal areas, nevertheless, this remains to be answered through exhaustive research. Additionally, this figure shows how the SST increased during the El Niño period of 2018-2019. Considering the 
limitations of our data and the superposition of different physical processes, we could not develop an accurate interpretation of cause and effect for the observed results in GP and its relation to regional conditions, especially as the coupled ocean-atmosphere system affects biological processes which can also modify the low and high-frequency variability. Despite this fact, we consider that wind intensification leads to an interaction between upwelled coastal waters and the CRTD, probably in the form of anticyclonic rings that transport water off Papagayo in a northwestward direction (Vargas, 2002). Previous studies have indicated that the upwelling plumes of Papagayo block the northward flow of the Costa Rica Coastal Current (CRCC), attributing the formation of Papagayo eddies to the conservation of potential vorticity of the CRCC when it interacts with sustained forcing by the wind (Ballestero \& Coen, 2004).

Upwelling is in many parts of the Eastern Tropical Pacific an important factor to local dynamics (Fiedler \& Lavin, 2017). Based on the data collected on this research, the GP shows a similar variability to the Gulf of Panama. In both places, a seasonal upwelling has been associated with the annual migration of the Intertropical Convergence Zone (ITCZ) (Poveda, Waylen, \& Pulwarty, 2006). From December to mid-April, the ITCZ migrates south of the Isthmus of Panama, intensifying the northeast trade winds across the region and bringing cold, nutrient-rich, deep water up and onto the shelf (D'Croz \& O'Dea, 2007). Such wind-driven upwelling events can reduce SST in the Gulf of Panama by $10{ }^{\circ} \mathrm{C}$ within a few days to weeks, and this also coincides with bottom temperature in GP, where temperature values can drop by $15{ }^{\circ} \mathrm{C}$ in the outer part of the gulf.

Along with cold waters, a slight shoaling of the oxycline to depths of around 45 to $50 \mathrm{~m}$ occurred especially during the negative ENSO phase in 2018 and the upwelling season. While the vertical migration of the oxycline can take place in any stratified ocean region, the minimum concentration of $<1 \mathrm{mg} / \mathrm{L}$ could be attributed to the influence of the Oxygen Minimum Zone of the ETP, which has its wider vertical extension around the CRTD (Fiedler \& Lavin, 2017). The Costa Rica Dome is similar to other tropical thermocline domes in several aspects: it is part of an east-west thermocline ridge associated with the equatorial circulation, surface currents flow cyclonically around it, and its seasonal evolution is affected by largescale wind patterns. The Costa Rica Dome is unique because it is also forced by a coastal wind jet. A seasonally predictable, strong, and shallow thermocline makes the Costa Rica Dome a distinct biological habitat that provides important ecosystem services on a regional and global scale (Johnson et al., 2018).

Primary productivity was in general moderate to high in GP, compared to previous studies conducted in the area (Álvarez et al. 2018; Ruiz, 2018) that registered chlorophyll-a concentrations above $0.5 \mathrm{mg} / \mathrm{m}^{3}$ all year over. The chlorophyll peak values coincided with the depth of the $25^{\circ} \mathrm{C}$ isotherm. During the ENSO negative phase, chlorophyll values were considerably higher, confirming the results of measurements and numerical models run for the Eastern Tropical Pacific which predict La Niña conditions boost the primary production as the chlorophyll levels are related to changes in the supply of nitrate rich-waters through vertical mixing and upwelling (Marrari et al., 2017; Sasai, Richards, Ishida, \& Sasaki, 2012). The subsurface chlorophyll maximum, usually located at depths of $35 \mathrm{~m}$ in September, disappeared during the upwelling periods to make way to a vertically homogeneous distribution in the most superficial layer of the water column with higher values, suggesting the intrusion of subsurface waters from deeper levels towards the surface (above $20 \mathrm{~m}$ depth) and the role of vertical mixing induced by wind. This homogeneity of the most superficial levels in the first trimester of the year reflects how the absence of lateral sources of freshwater, turbulent mixing induced by the wind and upwelling processes are the modulating factors of the vertical structure of the water column during the dry period (Álvarez et al., 2018). 
The minimum salinity of station 18 was in November 2017, matching weather station data in which maximum precipitation occurred over the last trimester of 2017. This suggests that river discharge and runoff influence the salinity in GP and also that advection from the Tropical Surface Water mass (TSW) could be influencing the dynamics inside GP. TSW is characterized in this region of the ETP for having salinities less than 34 PSU and temperatures above $25{ }^{\circ} \mathrm{C}$ (Brenes, Kwiecinski, D’Croz, \& Chávez, 1995), due to the excess of precipitation over evaporation in this region and high solar radiation incidence throughout the year (Amador et al., 2016).

Comparing our results to surrounding areas within the upwelling influence region, such as Golfo de Santa Elena, there is a clear difference in the chlorophyll ranges. For example, in September, values in GP are usually lower than the ones reported in Bahía Santa Elena that can go up to $1.5 \mathrm{mg} / \mathrm{m}^{3}$ (Tisseaux-Navarro, Salazar-Ceciliano, Cambronero-Solano, Vargas-Hernández, \& Marquez, 2021). In the outer parts of Golfo de Santa Elena, chlorophyll concentrations show similar maximum values of $7.5 \mathrm{mg} / \mathrm{m}^{3}$ on upwelling periods (Ballestero, Murillo, Vargas, \& Tisseaux, 2017). Although GP is an environment influenced by coastal upwelling, primary productivity is not as high as in Golfo de Santa Elena, which can be attributed to the wind magnitude which is reduced in GP by the Peninsula de Papagayo mountains in the Santa Rosa National Park, which appears to block part of the trade winds from NE direction. Another aspect that could explain the difference between these adjacent gulfs is the bathymetry and the coastline orientation relative to prevailing wind direction.

We recommend generating extended timeseries data by installing fixed pressure sensors or ADCP moorings to compare with wind data to better understand its effects on the hydrographic variability and circulation in GP. Since GP is the birth of the CRTD, understanding its dynamics means a better understanding of the CRTD and the Eastern Tropical Pacific Oxygen Minimum Zone effects in coastal waters, which could eventually input better management of fisheries and living resources in the Costa Rican Exclusive Economic Zone (Johnson et al., 2018).

Ethical statement: authors declare that they all agree with this publication and made significant contributions; that there is no conflict of interest of any kind; and that we followed all pertinent ethical and legal procedures and requirements. All financial sources are fully and clearly stated in the acknowledgements section. A signed document has been filed in the journal archives.

See Digital Appendix at: revistas.ucr.ac.cr

\section{ACKNOWLEDGMENTS}

To Vicerrectoría de Investigación, Universidad Nacional for the project funding and Fundación MarViva for the financial support with research vessels.

\section{RESUMEN}

\section{Variabilidad hidrográfica en el Golfo de Papagayo durante el periodo 2017-2019}

Introducción: El Golfo de Papagayo (GP) es un sitio de alta importancia socioeconómica ubicado en el Pacifico Norte de Costa Rica. Los servicios ecosistémicos de este sitio representan un beneficio a las comunidades locales, y su dinámica está influenciada por un sistema de surgencia costera que influye en la actividad pesquera y comercial.

Objetivo: El objetivo de este estudio fue caracterizar la variabilidad espacio-temporal de los principales parámetros hidrográficos a través de mediciones in situ durante el período 2017-2019.

Metodología: Se realizaron 8 campañas de medición, donde se desplegó una sonda CTD para realizar perfiles verticales en 23 estaciones distribuidas en todo el GP, para caracterizar las variaciones de temperatura, salinidad, oxígeno disuelto y concentración de clorofila.

Resultados: En el primer período del año se encontró una temperatura mínima de superficie y fondo asociada a la surgencia causada por el viento. El aumento de salinidad estuvo asociado a la disminución en la temperatura, siendo su valor más alto en el primer período del año y disminuyendo hasta alcanzar un mínimo en Noviembre. Los valores más altos de clorofila estuvieron relacionados con las temperaturas más bajas en superficie y los valores más 
bajos de oxígeno con las temperaturas más bajas en fondo. Se caracterizó la hidrografía de Bahía Culebra en relación con la parte externa de GP.

Conclusiones: La batimetría determina una asimetría surnorte de salinidad y temperatura. Los eventos de enfriamiento subsuperficiales coinciden con períodos de fuertes vientos. La surgencia influye en la dinámica hidrográfica de superficie y fondo en GP y determina la variabilidad interanual. El evento La Niña de 2018 mostró el período de surgencia más fuerte, posiblemente promoviendo la interacción de las aguas costeras y el Domo Térmico de Costa Rica.

Palabras clave: afloramiento costero; Pacífico Tropical Oriental; hidrografía; ENOS; Golfo de Papagayo.

\section{REFERENCES}

Alfaro, E. J. (2014). Caracterización del "veranillo" en dos cuencas de la vertiente del Pacífico de Costa Rica, América Central. Revista de Biología Tropical, 62(Supplement 4), S1-S15.

Alfaro, E. J., \& Cortés, J. (2012). Atmospheric forcing of cool subsurface water events in Bahía Culebra, Gulf of Papagayo, Costa Rica. Revista de Biología Tropical , 60(Supplement 2), S173-S186.

Alfaro, E. J., \& Lizano, O. G. (2001). Algunas relaciones entre las zonas de surgencia del Pacífico Centroamericano y los Océanos Pacífico y Atlántico Tropical. Revista de Biología Tropical, 40(Supplement 2), S185-S193.

Alfaro, E. J., Cortés, J., Alvarado, J. J., Jiménez, C., León, A., Sánchez-Noguera, C., Nivia-Ruiz, J. \& Ruiz, E. (2012). Clima y temperatura sub-superficial del mar en Bahía Culebra, Golfo de Papagayo, Costa Rica. Revista de Biología Tropical, 60(Supplement 2), S159-S171.

Álvarez, S. L., Benavides-Morera, R., Brenes-Rodríguez, C. L., \& Saxon, D. B. (2018). Estructura del fitoplancton en las épocas seca y lluviosa en el Golfo de Papagayo, Costa Rica. Revista Ciencias Marinas y Costeras, 10(2), 9-30.

Amador, J. A., Alfaro, E. J., Lizano, O. G., \& Magaña, V. O. (2006). Atmospheric forcing of the Eastern Tropical Pacific: A review. Progress in Oceanography, 69(2-4), 101-142.

Amador, J., Rivera, E., Durán-Quesada, A., Mora, G., Sáenz, F., Calderón, B., \& Mora, N. (2016). The easternmost tropical Pacific. Part II: Seasonal and intraseasonal modes of atmospheric variability. Revista de Biología Tropical, 64(Supplement 1), S23-S57.

Barua, D. K. (2005). Coastal Upwelling and Downwelling. In M. L. Schwartz (Ed.), Encyclopedia of Coastal
Science (pp. 306-308). Encyclopedia of Earth Science Series. Dordrecht: Springer.

Ballestero, D., \& Coen, J. E. (2004). Generation and propagation of anticyclonic rings in the Gulf of Papagayo. International Journal of Remote Sensing, 25(11), 2217-2224.

Ballestero, D., Márquez, A., Salazar, P., \& Murillo, G. (2012). Condiciones Oceanográficas en el Golfo de Papagayo. Informe Técnico. Heredia, Costa Rica: Universidad Nacional, Laboratorio de Oceanografía.

Ballestero, D., Murillo, G., Vargas, M., \& Tisseaux, A. (2017, November). Investigación multidisciplinaria en el sistema de surgencia del golfo Santa Elena, Pacífico norte de Costa Rica. $17^{\circ}$ Congresso LatinoAmericano de Ciências do Mar, Santa Catarina, Brasil. http://www.aoceano.com/site/images/pdf/ livro_resumos_colacmar_2017.zip

Brenes, C. L., Coen, J. E., Chelton, D. B., Enfield, D. B., León, S., \& Ballestero, D. (2003). Wind driven upwelling in the Gulf of Nicoya, Costa Rica. International Journal of Remote Sensing, 24(5), 1127-1133.

Brenes, C., Kwiecinski, B., D’Croz, L., \& Chávez, J. (1995). Características oceanográficas de la plataforma pacifica de América Central y aguas oceánicas adyacentes. Ciudad de Panamá, Panamá: Programa Regional de Apoyo al Desarrollo de la Pesca en el Istmo Centroamericano (PRADEPESCA).

Brenes, C. L., Lavín, M. F., \& Mascarenhas Jr, A. S. (2008). Geostrophic circulation between the Costa Rica Dome and Central America. Deep Sea Research Part I: Oceanographic Research Papers, 55(5), 608-629.

Brenes, C., León, S., Gutiérrez, A., \& Arroyo, G. (1990) Condiciones Hidrográficas en la Región de los "Papagayos". Revista Geofísica, 33, 5-19.

Calambokidis, J., Steiger, G. H., Rasmussen, K., Urban, J., Balcomb, K. C., de-Guevara-P, P. L., Salinas-Z, M., Jacobsen, J. K., Baker, C. S., Herman, L. M, Cerchio, S., \& Darling, J. D. (2000). Migratory destinations of humpback whales that feed off California, Oregon and Washington. Marine Ecology Progress Series, 192, 295-304.

Chao, Y., Li, Z., Farrara, J. D., \& Hung, P. (2009). Blending sea surface temperatures from multiple satellites and in situ observations for coastal oceans. Journal of Atmospheric and Oceanic Technology, 26(7), 1415-1426.

Cho, H. Y., Oh, J. H., Kim, K. O., \& Shim, J. S. (2013). Outlier detection and missing data filling methods for coastal water temperature data. Journal of Coastal Research, 65, 1898-1903

D’Croz, L., \& O’Dea, A. (2007). Variability in upwelling along the Pacific shelf of Panama and implications for 
the distribution of nutrients and chlorophyll. Estuarine, Coastal and Shelf Science, 73(1-2), 325-340.

Fiedler, P. C. (2002). The annual cycle and biological effects of the Costa Rica Dome. Deep Sea Research Part I: Oceanographic Research Papers, 49(2), 321-338

Fiedler, P. C., \& Lavín, M. F. (2017). Oceanographic conditions of the eastern tropical Pacific. In P. Glynn, D. Manzello, \& I. Enochs (Eds.), Coral Reefs of the Eastern Tropical Pacific. Coral Reefs of the World (pp. 59-83). Dordrecht: Springer.

Fiedler, P. C., \& Talley, L. (2006). Hydrography of the eastern tropical Pacific: A review. Progress in Oceanography, 69, 143-180.

GEBCO Compilation Group (2020). GEBCO $2020 \quad$ Grid. https://doi.org/10.5285/ a29c5465-b138-234d-e053-6c86abc040b9

Gómez, R. A., García, O. S., \& Álvarez, R. (2012). Satellite observations of the effect of ENSO on the Tehuantepec and Papagayo upwellings. Interciencia, 37(11), $828-832$.

Gotlieb, Y., Pérez-Briceño, P., Hidalgo, H., \& Alfaro, E. (2019). The Central American Dry Corridor: a concensus statement and its backgroud. Revista Yu'am, $3(5), 42-51$

Hofmann, E. E., Busalacchi, A. J., \& Q’Brien, J. J. (1981). Wind generation of the Costa Rica dome. Science, 214(4520), 552-554.

IMN. (2008). Clima en Costa Rica: Pacífico Norte. Retrieved September 9, 2018 from https://www. imn.ac.cr/documents/10179/31165/PacificoNorte. pdf/4a0e8960-8c51-4390-8a8d-73d9d825d59b.

Jia, Y. R., Chen, M. X., \& Zuo, J. C. (2017). Lowfrequency variability of sea surface height in the tropical Pacific Ocean. Applied Mechanics and Civil Engineering, VI, 215.

Johnson, D. E., Salazar, E. R., Gallagher, A., Rees, A., Sheridan-Rodriguez, C., Cambronero-Solano, S., Rojas-Ortega, G., \& Barrio-Froján, C. (2018). Preventing plastics pervading an oceanic oasis: building the case for the Costa Rica Thermal Dome to become a World Heritage site in ABNJ. Marine Policy, 96, 235-242.

Jiménez, C. (2001). Seawater temperature measured at the surface and at two depths $(7$ and $12 \mathrm{~m})$ in one coral reef at Culebra Bay, Gulf of Papagayo, Costa Rica. Revista de Biología Tropical, 49(Supplement 2), S153-S161.

Jiménez, C., \& Cortés, J. (2003). Growth of seven species of scleractinian corals in an upwelling environment of the eastern Pacific (Golfo de Papagayo, Costa Rica). Bulletin of Marine Science, 72(1), 187-198.
JPL OurOcean Project. (2010). GHRSST Level 4 G1SST Global Foundation Sea Surface Temperature Analysis. Ver. 1. PO.DAAC, CA, USA. Retrieved February 18, 2021, from https://doi.org/10.5067/GHG1S-4FP01.

Kessler, W. S. (2006). The circulation of the eastern tropical Pacific: A review. Progress in Oceanography, 69(2-4), 181-217.

Lizano, O. G., \& Alfaro, E. J. (2014). Dinámica atmosférica y oceánica en algunos sitios del Área de Conservación Guanacaste (ACG), Costa Rica. Revista de Biología Tropical, 62(Supplement 4), S17-S31.

Magaña, V., Amador, J. A., \& Medina, S. (1999). The midsummer drought over Mexico and Central America. Journal of Climate, 12, 1577-1588.

Marrari, M., Piola, A. R., \& Valla, D. (2017). Variability and 20-year trends in satellite-derived surface chlorophyll concentrations in large marine ecosystems around south and western Central America. Frontiers in Marine Science, 4, 372.

May-Collado, L., \& Morales Ramírez, A. (2005). Presencia y patrones de comportamiento del delfín manchado costero, Stenella attenuata (Cetacea: Delphinidae) en el Golfo de Papagayo, Costa Rica. Revista de Biología Tropical, 53(1-2), 265-276.

McClain, C. R., Christian, J. R., Signorini, S. R., Lewis, M. R., Asanuma, I., Turk, D., \& Dupouy-Douchement, C. (2002). Satellite ocean-color observations of the tropical Pacific Ocean. Deep Sea Research Part II: Topical Studies in Oceanography, 49(13-14), 2533-2560.

McCreary, J. P., Lee, H. S., \& Enfield, D. B. (1989). The response of the coastal ocean to strong offshore winds: With application to circulations in the Gulfs of Tehuantepec and Papagayo. Journal of Marine Research, 47(1), 81-109.

Ménesguen, C., Delpech, A., Marin, F., Cravatte, S., Schopp, R., \& Morel, Y. (2019). Observations and mechanisms for the formation of deep equatorial and tropical circulation. Earth and Space Science, 6(3), 370-386.

Poveda, G., Waylen, P. R., \& Pulwarty, R. S. (2006). Annual and inter-annual variability of the present climate in northern South America and southern Mesoamerica. Palaeogeography, Palaeoclimatology, Palaeoecology, 234(1), 3-27.

González-Rodríguez, E., Villalobos, H., Gómez-Muñoz, V. M., \& Ramos-Rodríguez, A. (2015). Computational method for extracting and modeling periodicities in time series. Open Journal of Statistics, 5(6), 604.

Salyuk, P., Bukin, O., Alexanin, A., Pavlov, A., Mayor, A., Shmirko, K., Akmaykin, D. \& Krikun, V. (2010). Optical properties of Peter the Great Bay waters 
compared with satellite ocean colour data. International Journal of Remote Sensing, 31(17-18), 4651-4664.

Sasai, Y., Richards, K. J., Ishida, A., \& Sasaki, H. (2012). Spatial and temporal variabilities of the chlorophyll distribution in the northeastern tropical Pacific: The impact of physical processes on seasonal and interannual time scales. Journal of Marine Systems, 96, 24-31.

SINAC. (2008). GRUAS II: Propuesta de Ordenamiento Territorial para la conservación de la biodiversidad de Costa Rica. Volumen 3: Análisis de vacios en la Representatividad e Integridad de la biodiversidad marina y costera. San José, Costa Rica: Sistema Nacional de Áreas de Conservación (SINAC) del Ministerio de Ambiente, Energía y Telecomunicaciones (MINAET).

Tisseaux-Navarro, A., Salazar-Ceciliano, J. P., Cambronero-Solano, S., Vargas-Hernández, J. M., \& Marquez, X. (2021). Reverse circulation in Bahía Santa Elena, North Pacific of Costa Rica. Regional Studies in Marine Science, 43, 101671 .

Trasviña, A., Lluch, D., Filonov. A., \& Gallegos, A. (1999). Oceanografía y El Niño. In O. V. Magaña (Ed.), Los Impactos de El Niño en México (pp. 69-101). Ciudad de México, México: Universidad Nacional Autónoma de México.
Vargas, J. M. (2002). Interacción océano-atmósfera: surgencia y generación de anillos en la región de Papagayo. Revista Geográfica de América Central, 1(40), 133-144.

Vargas-Hernández, J. M., Salazar-Ceciliano, J. P., Benavides-Morera, R., Tisseaux-Navarro, A., \& Cambronero-Solano, S. (2019, June). Condiciones hidrográficas del Golfo de Papagayo en el Pacífico norte de Costa Rica. I Congreso Internacional de Ciencias Exactas y Naturales, San José, Costa Rica. https://doi. org/10.15359/cicen.1.28

Villalobos-Rojas, F., Herrera-Correal, J., Garita-Alvarado, C. A., Clarke, T., \& Beita-Jiménez, A. (2014). Actividades pesqueras dependientes de la ictiofauna en el Pacífico Norte de Costa Rica. Revista de Biología Tropical, 62(Supplement 4), S119-S137.

Virtanen, P., Gommers, R., Oliphant, T. E., Haberland, M., Reddy, T., Cournapeau, D., ... \& van der Walt, S. J. (2020). SciPy 1.0: fundamental algorithms for scientific computing in Python. Nature Methods, 17(3), 261-272.

Wang, W., \& McPhaden, M. J. (2001). Surface layer temperature balance in the equatorial Pacific during the 1997-98 El Nino and 1998-99 La Nina. Journal of Climate, 14(16), 3393-3407.

Wyrtki, K. (1966). Oceanography of the Eastern Equatorial Pacific Ocean. Oceanography Marine Biology Annual Review, 4, 33-68. 